Original Research

\title{
Benzene Degradation by Free and Immobilized Bacillus glycinifermantans Strain GO-13T Using GO Sheets
}

\author{
Hossein Mohammadpour ${ }^{1,2}$, Mahdi Shahriarinour ${ }^{3 *}$, Ramin Yousefi $^{4}$ \\ ${ }^{1}$ Department of Microbiology, Fars Science and Research Branch, Islamic Azad University, Fars, Iran \\ ${ }^{2}$ Department of Microbiology, Shiraz Branch, Islamic Azad University, Shiraz, Iran \\ ${ }^{3}$ Department of Microbiology, Rasht Branch, Islamic Azad University, Rasht, Iran \\ ${ }^{4}$ Department of Physics, Masjed-Soleiman Branch, Islamic Azad University, Masjed -Soleiman, Iran
}

Received: 6 July 2019

Accepted: 4 August 2019

\begin{abstract}
In the current study, biodegradation of benzene by free and immobilized bacteria using graphene oxide was studied under optimized conditions. Isolated benzene-degrading bacterium from contaminated soils was identified based on 16S rDNA gene sequencing and submitted to gene bank as Bacillus glycinifermentans Strain GO 13T. The optimum values of $\mathrm{pH}$, temperature and benzene concentration for benzene degradation by free and immobilized cells were determined as $7,32^{\circ} \mathrm{C}$ and $1.25 \mathrm{~g} / 1$, respectively using response surface methodology. Free cells were able to degrade $55.8 \%$ of Benzene after 24h under optimized conditions. Graphene oxide was used to immobilize Bacillus glycinifermentans Strain GO 13T. Analysis by FTIR and SEM showed that the strain adhered onto the graphene oxide surface and developed a biofilm. Immobilized cells were able to degrade up to $77 \%$ of benzene after $24 \mathrm{~h}$ under optimized conditions. Results indicated that free and immobilized cells had a suitable application potential in the treatment of benzene-containing soils.
\end{abstract}

Keywords: benzene biodegradation, graphene oxide, response surface methodology, SEM, FTIR

\section{Introduction}

Petroleum hydrocarbon compounds are commonly known as soil and groundwater contaminants. Bacteria need to come in physical contact with these compounds to degrade them. A wide variety of hydrocarbon degradation can be found due to the affinity of a bacterial strain toward a particular hydrocarbon. Due to

*e-mail: mahdi.shahriari@iaurasht.ac.ir the similarity in the structure of most of the aromatic hydrocarbon pollutants, it is possible that the bacterial strain showing affinity toward one hydrocarbon reveals an affinity toward other related aromatic hydrocarbons. Whenever there is physical contact between cells and pollutants, biofilm formation and surfactant production can take place for increasing hydrocarbon bioavailability and biodegradation [1]. Volatile monoaromatic hydrocarbons of crude petroleum and petroleum products, which are commonly found together, are benzene, toluene, ethylbenzene, and xylene [BTEX]. These compounds are dangerous to human 
health and are found or suspected carcinogens. As a result, the United States Environmental Protection Agency (US EPA) classifies them as environmental priority pollutants, which should be removed from critically polluted environments. These compounds, due to the lack of an activating oxygen or nitrogen substituent group (which could make oxidation of the ring more energetically possible) are especially difficult to be degraded [1-2]. Benzene is known as a volatile and monoaromatic compound in petroleum products [34]. It is widely used in industry as a solvent for organic synthesis, equipment cleaning, and other downstream processing purposes. It is present in refinery and chemical industry effluents. Benzene compounds are frequently found in groundwater because of their leaking into underground storage tanks and pipelines, improper waste disposal practices, and inadvertent spills and leaching from landfills [5]. These pollutants cause many serious health effects to humans (e.g., skin and sensory irritation, central nervous system depression, respiratory problems, leukemia, cancer, as well as a disturbance in the kidney, liver, and blood systems [5-6]. During the past several decades, a number of remediation techniques including biological (e.g., bioventing and phytoremediation), chemical (e.g., chemical oxidation and soil flushing), and physical (e.g., soil vapor extraction and thermal treatment) methods have been developed for the subsurface remediation of BTEX-contaminated soil and groundwater systems [7-8]. The utilization of a biodegrading microorganism of BTEX compounds seems to be a promising method to overcome this problem. Aerobic bacteria, which are capable of BTEX degrading, are widely distributed in nature. Research on the genetics and metabolism of BTEX degraders suggests that Pseudomonas is mostly able to degrade BTEX [9]. Furthermore, related Ralstonia and Burkholderia species are involved in BTEX degradation [7]. In addition, Rhodococcus, Marinobacter Acinetobacter, Alcaligenes, Brevibacterium, Cladophialophora sp. strain T1 Nocardia, Bacillus, Bordetella, Arthrobacter, Bradyrhizobium, Acidovorax, Agrobacterium, Aquaspirillum, Variovorax and Stenotrophomonas were found to degrade BTEX in soil [10-11]. A variety of factors, such as active biomass concentration, pollutant concentration, $\mathrm{pH}$, and temperature, the availability of inorganic nutrients and electron acceptors, and microbial adaptation can influence the extent and rate of biodegradation of BTEX.

Moreover, the immobilized microorganism technology can be applied in biological treatments to enhance the efficiency and effectiveness of biodegradation, giving higher specific surface areas for microbial growth with better resistance against chemical toxicities and environmental stresses (e.g., $\mathrm{pH}$, temperature, and toxic substances) [12]. Graphene as an acceptor can increase the lifetime of the electron-hole pairs. Also, it can increase the adsorption of pollutants due to the non-covalent interaction between organic pollutants and the aromatic regions of graphene, which can also be an immobilizer for microorganisms that give the higher metabolism and degradation of BTEX [13-14]. This study aims to isolate a bacterial strain with benzene degradation ability and to investigate benzene biodegradation by free-living and graphene oxide (GO)-immobilized cells of the isolate. This was the first time that GO has been used as a suitable compound for the immobilization of some gram positive and negative bacteria to enhance BTEX biodegradation efficiency. Furthermore, the effects of GO concentration, environmental conditions such as $\mathrm{pH}$, temperature, and benzene concentration on the biodegradation efficiency of Benzene are evaluated.

\section{Material and Methods}

\section{Medium and Culture Conditions}

An enrichment culture technique isolated the Benzene-degrading strain (GO-13T) in a medium containing benzene as the sole carbon and energy source from contaminated soil, collected from MasjedSoleiman $\left(31.9634^{\circ} \mathrm{N}, 49.2892^{\circ} \mathrm{E}\right)$ located in Khuzestan Province, Iran. The sampling site was contaminated by a variety of industrial waste products related to the oil and gas industry, that had been released over the decades. In September 2016, we collected 24 soil samples from depths of $10 \mathrm{~cm}$ and $25 \mathrm{~cm}$ in the studied area. A total of 24 soil samples from the sampling site were then taken to obtain representative composite soil samples. They were chilled at $4^{\circ} \mathrm{C}$ during the transfer of the sample to the lab, and stored at $-20^{\circ} \mathrm{C}$ to carry out bacterial isolation and DNA [15-16]. The $\mathrm{pH}$ value of the medium was adjusted to 7.0, and the medium was autoclaved to sterilize at $121^{\circ} \mathrm{C}$ for $15 \mathrm{~min}$. Benzene with $99.5 \%$ purity (Merck, Germany) was then added to the sterilized medium to a final concentration of $1 \%$ $(\mathrm{v} / \mathrm{v})$ as the sole carbon and energy source. The strain TY4-HX was grown aerobically in MSM at $30^{\circ} \mathrm{C}$ on a shaker at $150 \mathrm{rpm}$ for seven days. The culture medium was then transferred to a new MSM medium to incubate for another seven days. This procedure was replicated three times. The final enrichment cultures were transferred onto the benzene-containing agar plates [15-16].

\section{Identification of Selected Strain by $16 \mathrm{~S}$ rDNA Sequencing}

Ribotyping analysis was carried out by TopazGene Company (Karaj- Iran). Briefly, DNA extraction was carried out using a top general genomic DNA extraction kit (cat NO. TGK1003; TopazGene Co., Iran). Based on the manufacturer's recommendation, the 16S rRNA gene was amplified using Top Bacterial 16s Ribosomal DNA amplification 2X Master mix (cat No TGI4001) and universal primers $27 \mathrm{f}$ and $1492 \mathrm{R}$. The preparations 
of the reactions and PCR program were done according to the manufacturer's recommended procedure. On this basis, the amplification was performed in a reaction mixture of polymerase chain reaction (PCR) with 10xTaq buffer, 1.25 U AmpliTaqGold DNA polymerase, two mM dNTP mixture, $25 \mathrm{mM} \mathrm{MgCl2,} 0.7 \mathrm{mg}$ DNA, and double-distilled water, which were mixed in a final volume of $50 \mathrm{ml}$. The PCR program was set as follows: 1 cycle of $94^{\circ} \mathrm{C}$ for $5 \mathrm{~min}, 30$ cycles of $94^{\circ} \mathrm{C}$ for $1 \mathrm{~min}, 55^{\circ} \mathrm{C}$ for $1 \mathrm{~min}$, and $72^{\circ} \mathrm{C}$ for $1 \mathrm{~min}$, with one extension cycle at $72^{\circ} \mathrm{C}$ for $10 \mathrm{~min}$. The amplified product was visualized using horizontal electrophoresis of $1 \%$ agarose gel after staining with safe DNA staining. Amplified DNA was sequenced by Microsynth Company (Switzerland). Amplified DNA was sequenced by Microsynth bioinformatics analysis, which was carried out using MEGA6 software and EzBioCloud 16 s database. Phylogenetic trees were obtained from MEGA6 software [17-18].

\section{Design of Experiments and Modeling}

Response surface methodology (RSM) as a statistical method could be implemented in order to determine the relationship among a certain response and a group of factors that are of importance to the investigator. This model is built to describe the response over specific ranges of the interesting factors. The response surface is addressed as the fitted model in many industrial applications, due to the capability of the response which can then be graphed as a line (curve) for one interesting factor or a surface for two interesting factors. Often the RSM is used to identify the range of operating conditions that can lead to the optimum response and satisfy certain operating or process specifications [16]. RSM also may be used to identify new operating conditions that would improve product quality, while correlating among the response and the main quantitative factors. A number of 30 runs with seven replications in the center point were selected to determine the initial $\mathrm{pH}$, temperature, benzene, and graphene oxide concentration for attaining the maximum degradation of benzene. After determining the ranges of the optimum values, a full central composite design (CCD) was utilized to find the optimum conditions of the four factors $\left(\mathrm{X}_{1}, \mathrm{X}_{2}, \mathrm{X}_{3}\right.$, and $\mathrm{X}_{4}$ ) [19-20]. RSM with a four-factor, three-level CCD design was used to optimize the response, Y (benzene degradation) of four variables:

$$
\begin{gathered}
\mathrm{Y}=\mathrm{b}_{0}+\mathrm{b}_{1} \mathrm{X}_{1}+\mathrm{b}_{2} \mathrm{X}_{2}+\mathrm{b}_{3} \mathrm{X}_{3}+\mathrm{b}_{4} \mathrm{X}_{4}+\mathrm{b}_{11} \mathrm{X}_{2} \\
+\mathrm{b}_{22} \mathrm{X}_{2}+\mathrm{b}_{33} \mathrm{X}_{2}+\mathrm{b}_{44} \mathrm{X}_{2}
\end{gathered}
$$

...where $\mathrm{Y}$ is the predicted response; $\mathrm{X}_{1}, \mathrm{X}_{2}, \mathrm{X}_{3}$ and $\mathrm{X}_{4}$ show temperature $\left({ }^{\circ} \mathrm{C}\right)$, benzene concentration $(\mathrm{g} / \mathrm{l})$, $\mathrm{pH}$ value and graphene oxide concentration (g/l), respectively; $b_{0}$ is the intercept term; $b_{1}, b_{2}, b_{3}$, and $b_{4}$ represent linear coefficients; $b_{11}, b_{22}, b_{33}$, and $b_{44}$ denote
Table 1. Levels and codes of variables for central composite design.

\begin{tabular}{|c|c|c|c|}
\hline \multirow{2}{*}{ Variables } & \multicolumn{3}{|c|}{ Level code } \\
\cline { 2 - 4 } & -1 & 0 & 1 \\
\hline $\mathrm{X}_{1}$ & 0.05 & 0.28 & 0.5 \\
\hline $\mathrm{X}_{2}$ & 0.5 & 1.25 & 2 \\
\hline $\mathrm{X}_{3}$ & 6 & 7 & 8 \\
\hline $\mathrm{X}_{4}$ & 24 & 32 & 40 \\
\hline
\end{tabular}

$\mathrm{X}_{1}$ : GO concentration; $\mathrm{X}_{2}$ : Benzene concentration; $\mathrm{X}_{3}: \mathrm{pH}$; $\mathrm{X}_{4}$ : Temperature

squared coefficients; and $b_{12}, b_{23}, b_{13}, b_{14}, b_{24}$ and $b_{34}$ are interaction term of the model [20]. The actual factor level corresponding to the coded factor levels are shown in Table 1. The ranges of factor levels for the experimental design were selected based on the literature. The optimal culture conditions for maximum benzene degradation and the coefficients in the secondorder polynomial (Eq. 1) were calculated by statistical analysis using Design Expert Software (version 6.0.6).

\section{Benzene Biodegradation Assay}

Bacterial isolate was grown $24 \mathrm{~h}$ at $32^{\circ} \mathrm{C}, 150 \mathrm{rpm}$, in MSM broth supplemented with $1 \%(\mathrm{v} / \mathrm{v})$ benzene under aerobic conditions. Cells were harvested by centrifuge $(10,000 \times \mathrm{g}$ for $10 \mathrm{~min})$, washed twice in sterile MSM broth and resuspended in one-tenth volume medium. Bacterial suspension at density equal to 0.5 McFarland was used as inoculum to predict the optimal medium composition for benzene degradation. The benzene degradation was done by dissolving residual benzene of medium in $3 \mathrm{ml} n$-hexane and reading the optical density against a blank at 200-400 nm wavelengths, and benzene concentrations were analyzed periodically by solid phase micro extraction followed by gas chromatographic detection using a gas chromatograph. Gas chromatographic experiments were performed with a GC- CP-3800 from Varian Company, Australia, equipped with a flame ionization detector (FID), a 1177 split/splitless injector, a cp-spill $8 \mathrm{CB}(30 \mathrm{~m}, 0.32 \mathrm{~mm}, 0.25 \mu \mathrm{m})$, and helium as a carrier gas with a constant flow rate of $2 \mathrm{~mL} / \mathrm{min}$. Chromatographic experiment run time was set to $10 \mathrm{~min}$ using a temperature programming starting from $40^{\circ} \mathrm{C}$ to $150^{\circ} \mathrm{C}$. Compounds were separated through, and since the abiotic loss was observed during prolonged incubation times, benzene biodegradation was estimated by measuring differential disappearance of these compounds in the test solution containing TY4-HX, and in control, a solution prepared under the same condition in the absence of TY4-HX (abiotic control solution). Results were expressed as the residual percentage of benzene as $\left(C_{t} / C_{d}\right)^{*} 100$, where $C_{t}$ is the benzene concentration in the test solution containing 
TY4-HX, and $C c$ is the benzene concentration in the abiotic control solution [21-22].

\section{Preparation and Characterization of Graphene Oxide (GO)}

High-purity graphene oxide powder (GO 99.999\%) with 6-10 layers graphene oxide (GO) were purchased from US Research Nanomaterials INC, with 5-10 nm inner and 20-30 $\mathrm{nm}$ outer diameter, and surface area of $>110 \mathrm{~m}^{2} / \mathrm{g}$. For the synthesis, a GO solution with a concentration of $0.05 \mathrm{~g} / 1$ was prepared, and then it was ultrasonicated for $15 \mathrm{~min}$. After that, the GO solution was added to a $0.2 \mathrm{M}$ cysteine solution, which was connected to a reflux system. GO was changed to reduced graphene oxide (rGO) [14]. Characterization of the GO was done with the help of a scanning electron microscope (SEM, Seron model mira3) and fourier transform infrared (FTIR) (Perkin Elmer). Different amounts of $\mathrm{GO}(0.05,0.2,0.35,0.50$, $0.65 \mathrm{~g} / \mathrm{l})$ were dispersed in sterile distilled water under ultrasonic dispersion for $30 \mathrm{~min}$. Then $10 \mu \mathrm{l}$ of bacterial suspension of density equal to 0.5 McFarland was resuspended in MSM and $100 \mu \mathrm{l}$ of different amounts of GO was added. The incubation temperature, $\mathrm{pH}$, and initial concentration of benzene were adjusted based on optimum conditions obtained by RSM. After incubation for $24 \mathrm{~h}$ with shaking at $150 \mathrm{rpm}$, benzene degradation was determined. The GO with adhered strain were analyzed using scanning electron microscopy (SEM) and fourier transform infra-red (FTIR) techniques. For SEM analysis, GO was rinsed three times with sterile distilled water to remove unattached cells. Afterward, they were observed via SEM. FTIR studied the surface organic structures of the GO. Spectra recorded at four $1 / \mathrm{cm}$ and $0.011 / \mathrm{cm}$ of resolution between 4000 and 500 1/cm using a Perkin Elmer Spectrum two series model instrumental analysis with the $\mathrm{KBr}$ disc method [14].

\section{Results and Discussion}

\section{Benzene-Degrading Isolates Characterization}

Fig. 1 shows the SEM image of the GO sheets that were used in this research. It can be seen, and the GO was included a few layers that are completely separated.

After sampling from oil-contaminated soils and enrichment procedures in MSM benzene-containing broth, the benzene-degrading bacterial strain with the best growth in the presence of benzene was selected.

The observation of bacterial growth on MSM benzene-containing agar plates revealed that the bacterial cells of the selected isolate were Grampositive, motile, facultatively anaerobic, endosporeforming rods, and with a diameter of $0.5-0.8 \mathrm{~mm}$ and length of 1.7-4.8 mm. Central or subterminal ellipsoidal endospores were observed without swollen sporangi.

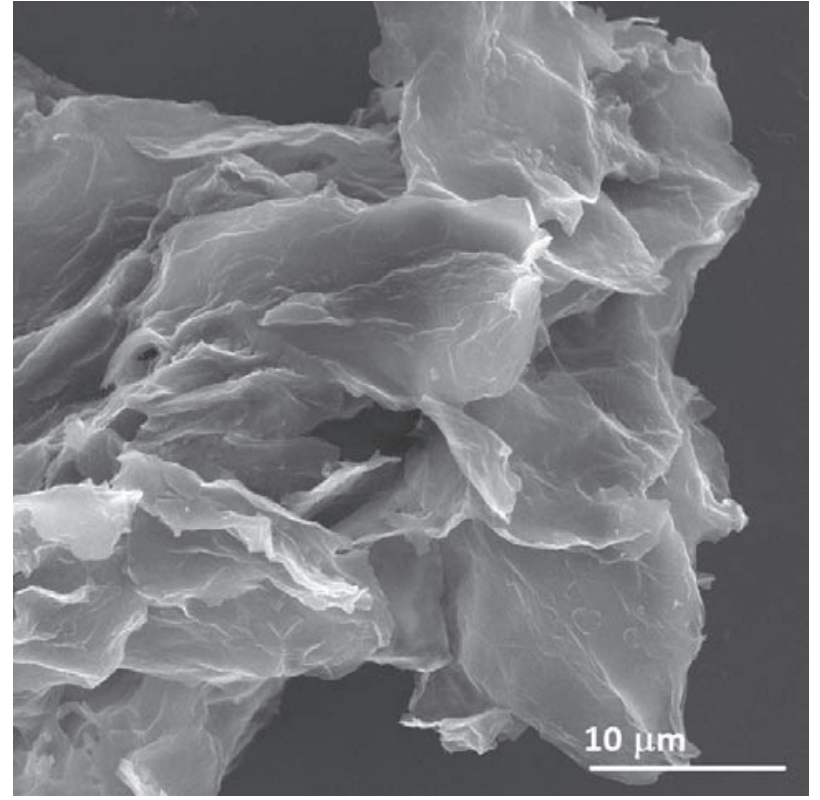

Fig. 1 SEM image of the GO sheets that were used in this research.

Bacterial colonies formed on nutrient agar were creamy white, mucoid, translucent, raised, and 3-4 $\mathrm{mm}$ in diameter. After two days of incubation at $37^{\circ} \mathrm{C}$, they were capable of growing at $15-55^{\circ} \mathrm{C}$ and could tolerate up to $8 \% \mathrm{NaCl}$. It produced catalase but not oxidase. Positive results were observed in tests for hydrolysis of casein, aesculin, gelatin, and starch, and tests of nitrate reduction and $\beta$-galactosidase activity [23]. Comparing the sequences of the obtained 16S rDNA gene from the isolate with the sequences in GeneBank revealed that this strain had the highest similarity (99.72\%) to Bacillus glycinifermantans strain GO-13T (1430 bases) under the accession number of LBMN01000156. This genus bacterium was used for degradation of aromatic hydrocarbons such as monoaromatic hydrocarbons (MAHs) and polyromantic hydrocarbons (PAHs)[24]. Bacillus genus has been the focus of several studies because of its possible applications in bioremediation. It is used as biological agents for removing the environmental pollutants. Fig. 3 illustrates

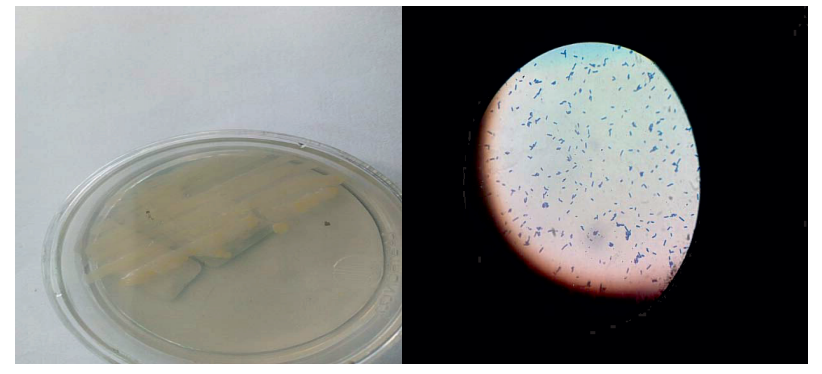

Fig. 2. Colonies and microscopic morphology of Bacillus glycinifermantans strain GO-13T on MSM benzene-containing agar plates. 


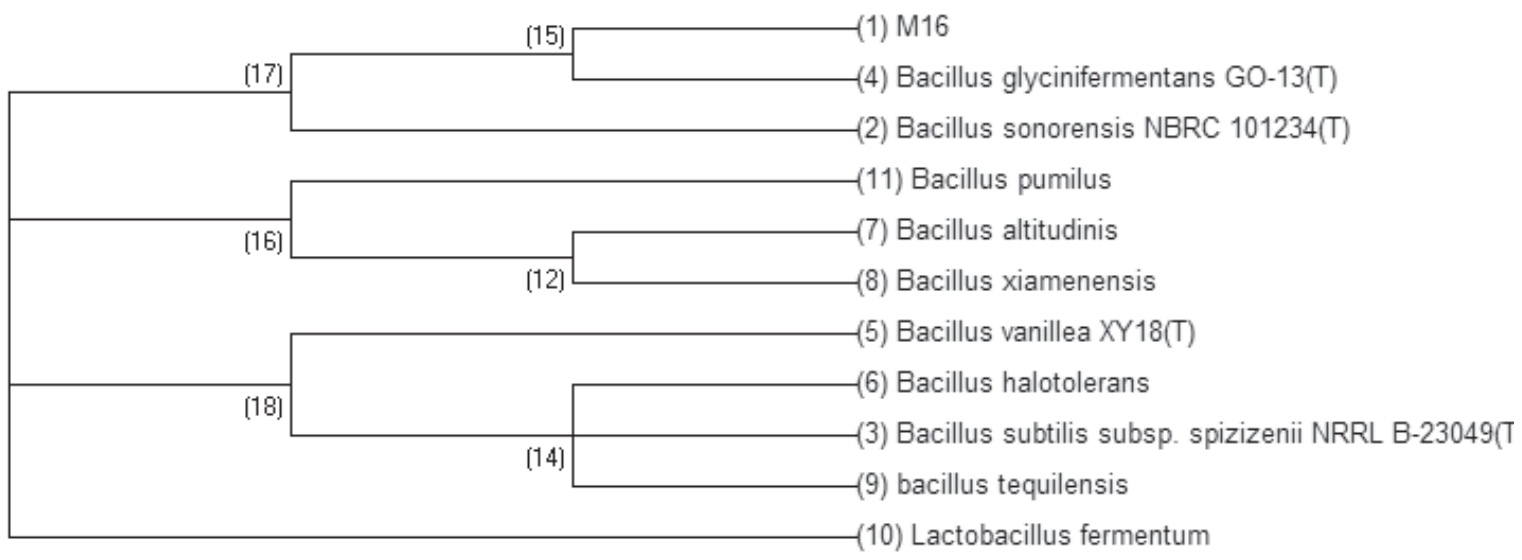

Fig. 3. Phylogenetic tree of the 16S rDNA sequence of Bacillus glycinifermentans Strains GO $13 T$ and related strains.

the phylogenetic tree of Bacillus glycinifermantans strain GO-13T that was constructed using the MEGA (version 6) [19].

\section{RSM Model Development}

Instead of optimizing medium composition by a onefactor-at-a-time approach, the statistical RSM design provides the opportunity to determine the optimal conditions in any given parameters by establishing the relationship between factors and predicted responses. The RSM design was applied to obtain the precise factor values that result in Table 2 .

\section{Benzene Biodegradation}

By applying multiple regression analysis to the experimentally determined data in Eq. (1), the regression coefficients were estimated, and the following secondorder polynomial equation was obtained for benzene biodegradation:

$$
\begin{gathered}
\mathrm{Y}=-1111.58+12.27 \mathrm{X}_{2}-155.94 \mathrm{X}_{1}^{2} \\
-21.39 \mathrm{X}_{3}^{2}-0.107 \mathrm{X}_{4}^{2}
\end{gathered}
$$

The predicted optimum levels of $\mathrm{X}_{1}, \mathrm{X}_{2}, \mathrm{X}_{3}$ and $\mathrm{X}_{4}$ were obtained by applying regression analysis (Eq. 2), and they were $0.28 \mathrm{~g} / \mathrm{l} \mathrm{GO}, \mathrm{pH}=7,32^{\circ} \mathrm{C}$ and $1.25 \mathrm{~g} / 1$ of benzene concentration. The prediction of benzene biodegradation was $73.95 \%$. The coefficient of determination $\left(\mathrm{R}^{2}\right)$ value of the regression for the response related to significant effects on the model was 0.9592 , which means that the sample variation of $95.92 \%$ for benzene degradation was attributable to the factors. The adequacy of the full quadratic model of benzene degradation was also evaluated with ANOVA. Model summary statistics in Table 3 indicated the adequacy of the models, including linear, 2-factor interactions, and quadratic terms. Linear and interaction models for benzene degradation were significant (Table 3). Figures S1-S3 in the supplementary material illustrate the interaction of $\mathrm{pH}$, temperature, and benzene concentration with GO concentration (including surface and contour plots in RSM).

\section{SEM Observations and FT-IR Analysis}

The bacterial adhesion on the surface of GO in the presence of $1.25 \mathrm{~g} / \mathrm{l}$ benzene was observed using SEM. Fig. 2 depicts bacteria cells trapped among the GO array bundles, which can be due to the interactions of bacteria cells with the external surfaces of GO arrays. Furthermore, Fig. 2 indicates that there are no significant changes in the morphology of the bacteria cells after incubating with GO arrays. These SEM images reveal that GO clusters only capture the bacteria cells due to sieve mechanisms without any damage to the cell wall. No changes were found in the structures of the GO after bacteria immobilized, which is the benefit of the method as observed in other studies [24-25]. This observation differs from other studies. The utilization of non-array graphene oxides has shown that graphene oxide rupture cell wall-membrane due to toxicity mechanisms such as oxidative stress and physical damage [26], while this observation has not been found in this study (Fig. 4).

Comparing the whole spectrum of $\mathrm{GO}$ and $\mathrm{GO} /$ Bacillus glycinifermentans Strain GO 13T are presented in Fig. 5, which reveals FTIR spectra of the products as well as the pristine GO sheets. For GO, the broad peak centered at $3232 \mathrm{~cm}^{-1}$ is attributed to the $\mathrm{O}-\mathrm{H}$ stretching vibrations. On the other hand, the peaks at $1719,1604,1367$, and $1271 \mathrm{~cm}^{-1}$ are assigned to the $\mathrm{C}=\mathrm{O}$ stretching, $\mathrm{sp}^{2}$-hybridized $\mathrm{C}=\mathrm{C}$ group, and $\mathrm{O}-\mathrm{H}$ bending, $\mathrm{C}-\mathrm{OH}$ stretching, and $\mathrm{C}-\mathrm{O}-\mathrm{C}$ stretching, respectively [27]. Also, the peaks at 1110 and $1014 \mathrm{~cm}^{-1}$ can be attributed to the $\mathrm{C}-\mathrm{O}$ vibration of the epoxy or alkoxy groups [28]. It can be seen that all peak positions of GO sheets are shifted, which is a sign of the interaction of benzene and GO sheets. However, some peaks belong to the benzene $617 \mathrm{~cm}^{-1}$ and $1104 \mathrm{~cm}^{-1}$ [27]. Besides, the peak at 
Table 2. Central composite design and its experimental values benzene degradation of Bacillus glycinifermantans strain GO$13 \mathrm{~T}$ using GO sheets.

\begin{tabular}{|c|c|c|c|c|c|}
\hline RUN & $\mathrm{X}_{1}$ & $\mathrm{X}_{2}$ & $X_{3}$ & $X_{4}$ & Y \\
\hline 1 & 0.05 & 2 & 8 & 24 & 38 \\
\hline 2 & 0.05 & 1.25 & 7 & 32 & 56 \\
\hline 3 & 0.28 & 1.25 & 6 & 32 & 48 \\
\hline 4 & 0.50 & 2 & 6 & 24 & 38 \\
\hline 5 & 0.28 & 1.25 & 7 & 32 & 77 \\
\hline 6 & 0.50 & 2 & 8 & 40 & 44 \\
\hline 7 & 0.50 & 2 & 8 & 24 & 40 \\
\hline 8 & 0.05 & 0.5 & 6 & 40 & 35 \\
\hline 9 & 0.05 & 2 & 6 & 24 & 38 \\
\hline 10 & 0.05 & 0.5 & 6 & 24 & 32 \\
\hline 11 & 0.28 & 2 & 7 & 32 & 71 \\
\hline 12 & 0.50 & 2 & 6 & 40 & 41 \\
\hline 13 & 0.05 & 2 & 6 & 40 & 47 \\
\hline 14 & 0.50 & 0.5 & 6 & 24 & 38 \\
\hline 15 & 0.05 & 2 & 8 & 40 & 33 \\
\hline 16 & 0.28 & 1.25 & 7 & 32 & 77 \\
\hline 17 & 0.50 & 0.5 & 8 & 40 & 36 \\
\hline 18 & 0.28 & 1.25 & 7 & 24 & 63 \\
\hline 19 & 0.28 & 1.25 & 7 & 32 & 77 \\
\hline 20 & 0.50 & 0.5 & 6 & 40 & 29 \\
\hline 21 & 0.28 & 1.25 & 7 & 32 & 77 \\
\hline 22 & 0.05 & 0.5 & 7 & 32 & 68 \\
\hline 23 & 0.28 & 1.25 & 7 & 32 & 70 \\
\hline 24 & 0.05 & 1.25 & 7 & 40 & 65 \\
\hline 25 & 0.05 & 0.5 & 8 & 40 & 36 \\
\hline 26 & 0.28 & 1.25 & 7 & 32 & 77 \\
\hline 27 & 0.05 & 0.5 & 8 & 24 & 33 \\
\hline 28 & 0.28 & 1.25 & 8 & 32 & 51 \\
\hline 29 & 0.50 & 0.5 & 8 & 24 & 30 \\
\hline 30 & 0.28 & 1.25 & 7 & 32 & 77 \\
\hline
\end{tabular}

$\mathrm{X}_{1}$ :Graphene oxid concenteration $(\mathrm{g} / \mathrm{l}), \mathrm{X}_{2}$ :Benzene concenteration $(\mathrm{g} / \mathrm{l}), \mathrm{X}_{3}: \mathrm{pH}, \mathrm{X}_{4}:$ Temperature $\left({ }^{\circ} \mathrm{C}\right)$,

Y: Benzene degredation (\%)

$2911 \mathrm{~cm}^{-1}$ belongs to the reduced graphene oxide (rGO) that was observed in our previous work [26]. Therefore, the FTIR results indicate that proper interaction was happened between this bacteria and GO sheets, and that GO sheets were changed into reduced graphene oxide (rGO) sheets during the biodegradation process (Fig. 5).

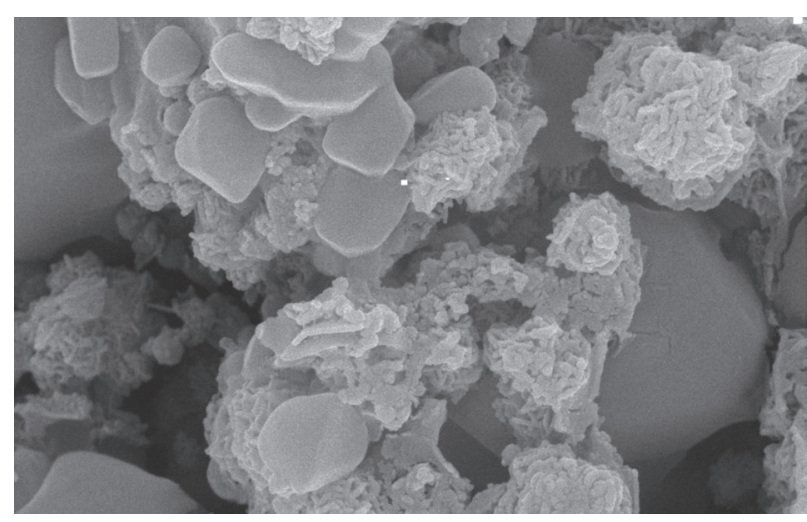

Fig. 4. Scanning Electron microscopy image ( $1 \mu \mathrm{m}$ resolution) of immobilized Bacillus glycinifermantans strain GO-13T using GO sheets.

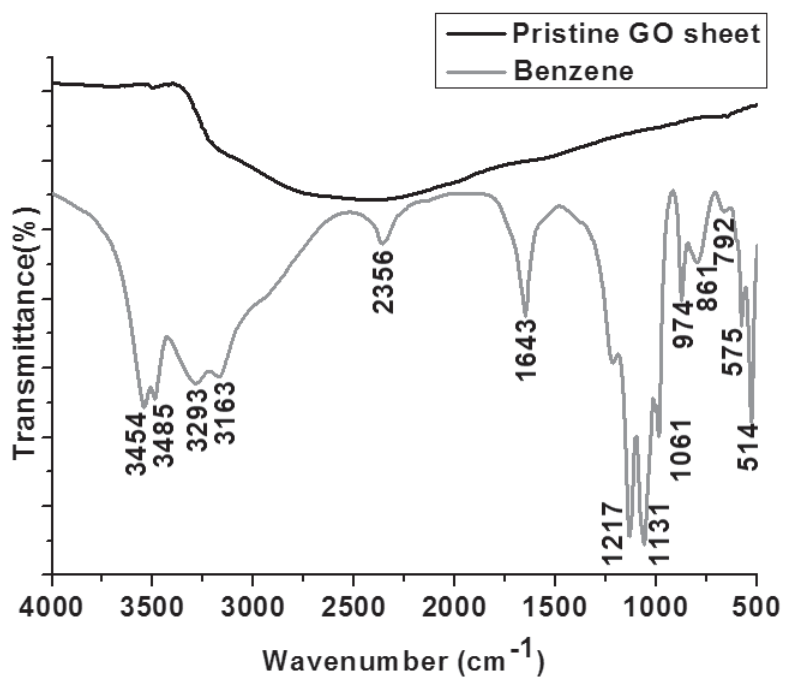

Fig. 5. Infrared spectrum of the G.O/ Bacillus glycinifermentans Strain GO 13T.

\section{Adsorption Performance of Free-Living and Immobilized Cells}

The removal of $1.25 \mathrm{~g} / \mathrm{l}$ benzene by the free and immobilized cells of Bacillus glycinifermentans Strain GO 13T with different amounts of $\mathrm{rGO}$ under an initial $\mathrm{pH}$ of 7 and a temperature of $32^{\circ} \mathrm{C}$ during $24 \mathrm{~h}$ and shaking at $150 \mathrm{rpm}$ was studied (Fig. 6). Besides, a higher benzene removal percentage was achieved by immobilized cells by $0.28 \mathrm{~g} / 1 \mathrm{GO}$. In this study, benzene, at $\mathrm{pH}$ of $7,32^{\circ} \mathrm{C}$, and an initial concentration of $1.25 \mathrm{~g} / 1$ was considerably degraded by $55 \%$ by the free-living cells and up to $77.3 \%$ by immobilized cells of Bacillus glycinifermentans Strain GO $13 T$ (Fig. 6). Similar studies have also shown that immobilized Bacillus cereus WJ1 with a multi graphene modified electrode was able to increase the biodegradation of phenol and also their repeated operation. Graphene showed better phenol adsorption 
Table 3. Analysis of variance (ANOVA) for benzene degredation of Bacillus glycinifermantans strain GO-13T using GO sheets response surface-reduced quadratic model.

\begin{tabular}{|c|c|c|c|c|c|}
\hline Source & Sum of Squares & DF & Mean Squre & F Value & Prob $>$ F \\
\hline Model & 8707.08 & 14 & 621.93 & 25.21 & $<0.0001$ \\
\hline $\mathrm{X}_{1}$ & 18 & 1 & 18 & 0.73 & 0.4065 \\
\hline $\mathrm{X}_{2}$ & 156.06 & 1 & 156.06 & 6.32 & 0.0238 \\
\hline $\mathrm{X}_{3}$ & 1.39 & 1 & 1.39 & 0.056 & 0.8157 \\
\hline $\mathrm{X}_{4}$ & 14.22 & 1 & 14.22 & 0.58 & 0.4595 \\
\hline $\mathrm{X}_{1}^{2}$ & 161.48 & 1 & 161.48 & 6.54 & 0.0218 \\
\hline $\mathrm{X}_{2}^{2}$ & 5.04 & 1 & 5.04 & 0.20 & 0.6578 \\
\hline $\mathrm{X}_{3}^{2}$ & 1185.95 & 1 & 1185.95 & 48.06 & $<0.0001$ \\
\hline $\mathrm{X}_{4}^{2}$ & 123.17 & 1 & 123.17 & 4.99 & 0.0411 \\
\hline $\mathrm{X}_{1} \mathrm{X}_{2}$ & 6.25 & 1 & 6.25 & 0.25 & 0.6221 \\
\hline $\mathrm{X}_{1} \mathrm{X}_{3}$ & 16 & 1 & 16 & 0.65 & 0.4333 \\
\hline $\mathrm{X}_{1} \mathrm{X}_{4}$ & 2.25 & 1 & 2.25 & 0.091 & 0.7668 \\
\hline $\mathrm{X}_{2} \mathrm{X}_{3}$ & 6.25 & 1 & 6.25 & 0.25 & 0.6221 \\
\hline $\mathrm{X}_{2} \mathrm{X}_{4}$ & 4 & 1 & 4 & 0.16 & 0.6929 \\
\hline $\mathrm{X}_{3} \mathrm{X}_{4}$ & 0.25 & 1 & 0.25 & 0.01 & 0.9212 \\
\hline Residual & 370.12 & 15 & 24.67 & & \\
\hline Lack of Fit & 370.12 & 10 & 37.01 & & \\
\hline Pure Error & 0 & 5 & 0 & & \\
\hline Cor Total & 9077.20 & 29 & & & \\
\hline Std. Dev. & 4.97 & & R-Squared & 0.95 & \\
\hline Mean & 51.40 & & Adj R-Squared & 0.92 & \\
\hline C.V. & 9.66 & & Pred R-Squared & 0.77 & \\
\hline PRESS & 2010.03 & & Adeq R-Squared & 12.52 & \\
\hline
\end{tabular}

$\mathrm{X}_{1}$ :Graphene oxid concenteration $(\mathrm{g} / \mathrm{l}), \mathrm{X}_{2}$ :Benzene concenteration $(\mathrm{g} / \mathrm{l}), \mathrm{X}_{3}: \mathrm{pH}, \mathrm{X}_{4}:$ Temperature $\left({ }^{\circ} \mathrm{C}\right), \mathrm{Y}$ : Benzene degredation $(\%)$ *Values of "Probability $>\mathrm{F}$ value" less than 0.05 indicates model terms are significant.

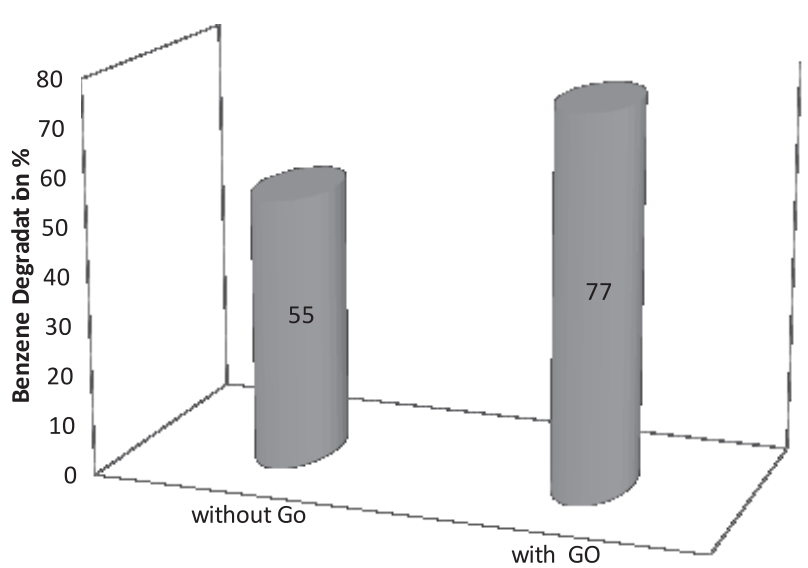

Fig. 6. Comparison of benzene removal percentage by freeliving cells and immobilized cells of Bacillus glycinifermentans Strain GO $13 T$ with GO. efficiency [29]. Positively charged benzene molecules attract the negatively charged molecules such as graphene oxide, which is an effective BTEX compound adsorbent with good potential of BTEX compound removal from wastewater [30-31]. Our previous study showed that Go had very good performance in eliminating the microbial xylene contained in the spill by Sphingomonas pucimobilis as an appropriate immobilizer [13]. It was the first time that Go has been used as a suitable compound for the immobilization of some gram positive and negative bacteria to enhance BTEX biodegradation efficiency. The adsorption mechanism of benzene on Go is mainly attributed to the $\pi-\pi$ electron donor-acceptor interaction between the aromatic ring of Benzene. 


\section{Conclusions}

This study investigated the biodegradation of Benzene using free and immobilized Bacillus glycinifermentans Strain GO 13T, which was isolated from contaminated soils collected from MasjedSoeilman in Khuzestan, Iran. Benzene-degrading bacterium with high biodegradation activity and high tolerance of benzene was capable of removing the benzene in liquid mineral salt medium by $55 \%$ over $24 \mathrm{~h}$. Moreover, graphene oxide (GO) was used to immobilize the strain TY4-HX. Analysis by FTIR and SEM showed the strain adhered onto the graphene oxide surface during the bacterial growth period. The immobilized cells possessed better storage stability and could remove benzene by $77 \%$ in $0.28 \mathrm{~g} / \mathrm{l} \mathrm{GO}$ during $24 \mathrm{~h}$. Based on the results; it is evident that benzene degradation by immobilized bacteria is higher than by bacteria alone, and the surface carboxylic groups of graphene oxide. Using response surface methodology, the optimum values of $\mathrm{pH}$, temperature and benzene concentration for benzene degradation by free and immobilized cells were determined as 7 , $32^{\circ} \mathrm{C}$ and $1.25 \mathrm{~g} / 1$, respectively. The unique properties of graphene oxide such as the very suitable surface for bonding and reaction with organic and mineral compounds in removing these compounds as well as the appropriate immobilizer to microorganisms like organic compounds' degrading bacteria ( $G O 13 T)$ make it a potential substance to be considered in further studies for enhancing the efficiency of decomposition rates.

\section{Acknowledgments}

The authors gratefully acknowledge the support of Shiraz Branch, Islamic Azad University and MasjedSoleiman Branch, Islamic Azad University, respectively.

\section{Conflict of Interest}

The authors declare no conflict of interest.

\section{References}

1. SINGH R., MARY CELIN S. Biodegradation of BTEX (Benzene, Toluene, Ethyl Benzene, and Xylene) compounds by Bacterial strain under Aerobic conditions. Journal of Ecobiotechnology. 2 (4), 27, 2010.

2. BRIGMON R., CAMPER D., STUTZENBERGER F. Bioremediation of compounds hazardous health and the environment. An overview. Progress in Industrial Microbiology. 36, 1, 2002.

3. TELIB A.E.E., EL-NAAS M.H., ACIO J.A. Biodegradation of BTEX: Optimization through Response Surface Methodology. American Journal of Engineering and Applied Sciences. 10 (1), 20, 2017.

4. BINA B., AMIN M.M., RASHIDI A., POURZAMANI H. Benzene and toluene removal by carbon nanotubes from aqueous solution. Archives of Environmental Protection. 36 (1), 3, 2012.

5. AIVALIOTI M., VAMVASAKIS I., GIDARAKOS E. BTEX and MTBE adsorption onto raw and thermally modified diatomite. Journal of Hazardous Materials. 178 (1-3), 136, 2010.

6. HEYDARNEZHAD F., HOODAJI M., SHAHRIARINOUR M., TAHMOURESPOUR A., SHAHRIATI S. Optimizing toluene degradation by bacterial strain isolated from oilpolluted soils. Polish Journal Environmental Studies. 27 (2), 1, 2018.

7. FIRMINO P.I.M., FARIAS R.S., BUARQUE P.M.C., COSTA M.C., RODRIGUEZ E., LOPES A.C., DOS SANTOS A.B. Engineering and microbiological aspects of BTEX removal in bioreactors under sulfate-reducing conditions. The Chemical Engineering Journal. 260, 503, 2015.

8. GUO H., YAO J., CHEN H., WANG J., MASAKORALA K., JIN Y., RICHNOW H.H., BLAKE R.E. Substrate interactions during biodegradation of benzene/ alkylbenzene mixtures by Rhodococcus sp. ustb-1. International Biodeterioration \& Biodegradation 75,124, 2012.

9. JIN H.M., CHOI E.J., JEON C.O. Isolation of a BTEXdegrading bacterium, Janibacter sp. SB2, from a seatidal flat and optimization of biodegradation conditions. Bioresource Technology. 145, 57, 2013.

10. PORZAMANI H.R., BINA B., RASHIDI A.M., AMIN M.M. Performance of raw and regenerated multi- and single-walled carbon nanotubes in xylene removal from aqueous solutions. International Journal of Environmental Health Engineering. 1 (4), 1, 2012.

11. YAN F.F., WU C., CHENG Y.Y., HE Y.R., LI W.W., YU H.Q. Carbon nanotubes promote $\mathrm{Cr}(\mathrm{VI})$ reduction by alginate-immobilized Shewanella oneidensis MR-1. Biochemical Engineering Journal. 77, 183, 2013.

12. DURSUN A.Y., TEPE O. Internal mass transfer effect on biodegradation of phenol by $\mathrm{Ca}$-alginate immobilized Ralstonia eutropha. Journal of Hazardous Materials 126 (1-3), 6105, 2005.

13. MOHAMMADPOUR H., SHAHRIARINOUR M., YOSEFI R. Xylene biodegradation by free and immobilized Sphingomonas paucimobilis strainTY4-HX by graphene oxide. Environmemtal Sciences. 16 (4), 63, 2019.

14. AZIMI H.R., GHORANNEVISS M., ELAHI M. Excellent photovoltaic and UV detector applications of $\mathrm{ZnS} / \mathrm{rGO}$ nanocomposites synthesized by a green method. Ceramics International. 42 (12), 14094, 2016.

15. STEFANI F.O.P., BELL T.H., MARCHAND C., PROVIDENCIA D.L., YASSIMI A.E., HIJRI M. Culture-dependent and independent methods capture different microbial community fractions in hydrocarboncontaminated soils. Plos One. 10 (6),128, 2015.

16. ZHAO X., WANG L., BAI S., YANG J., QI S. Pseudomonas sp. ZXY-1, a newly isolated and highly efficient atrazine-degrading bacterium, and optimization of biodegradation using response surface methodology. Journal of Environmental Science. 54, 152, 2017.

17. RANYA A., AMER R.A., NASEIR M.M., ELHELOW E.R. Biodegradation of Monocyclic Aromatic Hydrocarbons by a Newly Isolated Pseudomonas strain. Biotechnology. 7, 630, 2008.

18. MADUENO L., COPPOTELLI B.M., ALVAREZ H.M., MORELLI I.S. Isolation and characterization of indigenous soil bacteria for bio augmentation of $\mathrm{PAH}$ 
contaminated soil of semiarid Patagonia, Argentina. International Biodeterioration \& Biodegradation. 65 (2), 345, 2011.

19. YOON S.H., HA S.M., KWON S., LIM J., KIM Y., SEO H., CHUN J. A taxonomically united database of $16 \mathrm{~S}$ rRNA and whole genome assemblies. International Journal of Systematic and Evolutionary Microbiology. 67, 1613, 2017.

20. HUANG W., XUE A., NIU H., JIA Z.,WANG J. Optimized ultrasonic-assisted extraction of flavonoids from Folium eucommiae and evaluation of antioxidant activity in multitest systems in vitro. Food Chemistry 114 (3), 1147, 2009.

21. BERLENDIS S., LASCOURREGES J., SCHRAAUWERS B., SIVADON P., MAGO M.T. Anaerobic Biodegradation of BTEX by Original Bacterial Communities from an Underground Gas Storage Aquifer. Environmental Science and Technology. 44 (9), 3621, 2010.

22. JEAN J., LEO M.,WANG S.,CHATTOPADHYAY P., MAITY J. Effects of inorganic nutrient levels on the biodegradation of benzene, toluene, and Xylene (BTX) by Pseudomonas spp in a laboratory porous media sand aquifer model. Bioresource Technology. 99 (16), 7807, 2008.

23. KIM S., DUNLAP C.A., KWON S., ROONEY A.P. Bacillus glycinifermentans sp. nov., isolated from fermented soybean paste. International Journal of Systematic and Evolutionary Microbiology. 65 (10), 3586, 2015.

24. ZHANG J., XUE Q., GAO H., LAI H., WANG P. Bacterial degradation of crude oil using solid formulations of Bacillus strains isolated from oil-contaminated soil towards microbial enhanced oil recovery application. RSC Advances. 6, 5566, 2016.
25. KOLANGIKHAH M., MAGHREBI M., GHAZVINI K., FARHADIAN N. Separation of Salmonella typhimurium bacteria from water using MWCNTs arrays. International Journal of Nanoscience and Nanotechnology. 8 (1), 3-10, 2016.

26. NEL A., XIA T., MADLER L., LI N. Toxin potential of material at the nano level. Journal of Science. 311, 622, 2006.

27. NOURI M., MOGHADDAM S.A., AZIMI H.R., YOUSEFI R. High solar-light photocatalytic activity of using $\mathrm{Cu} 3 \mathrm{Se} 2 / \mathrm{rGO}$ nanocomposites synthesized by a green co-precipitation method. Solid State Sciences. 737, 2017.

28. GARRIGUES S., GALLIGNANI M., DE LA G.M. Simultaneous determination of ortho-, meta- and para-xylene by flow injection-Fourier transform infrared spectroscopy. Analyst. 117, 1849, 1992.

29. YAN Z., DABAN L., TIANZHEN J., LETAO W., SHAOXIOM G., YUE Z., CHUNMIN W., HAIJING H., YONGLING D. Biodegradation of phenol using Bacillus cereus WJ1 and evaluation of degradation efficiency based on a graphene-modified electrode. International Journal of Electrochemical Science. 8 (3), 504, 2013.

30. POURMAND S., ABDOUSS M., RASHIDI A.M. Preparation of nanoporous Graphene via Nanoporous ZincOxide and its application as a nanoadsorbent for Benzene, Toluene and Xylenes Removal. International Journal of Environmental Research. 9 (4),1269, 2013.

31. BEHZADI M., MIRZAEI M. Poly(o-anisidine)/ graphene oxide nanosheets composite as a coatingfor the headspace solid-phase microextraction of benzene, toluene,ethylbenzene and xylenes. Journal of Chromatography A. 1443, 35, 2016.

\section{Supplementary Material}

a)

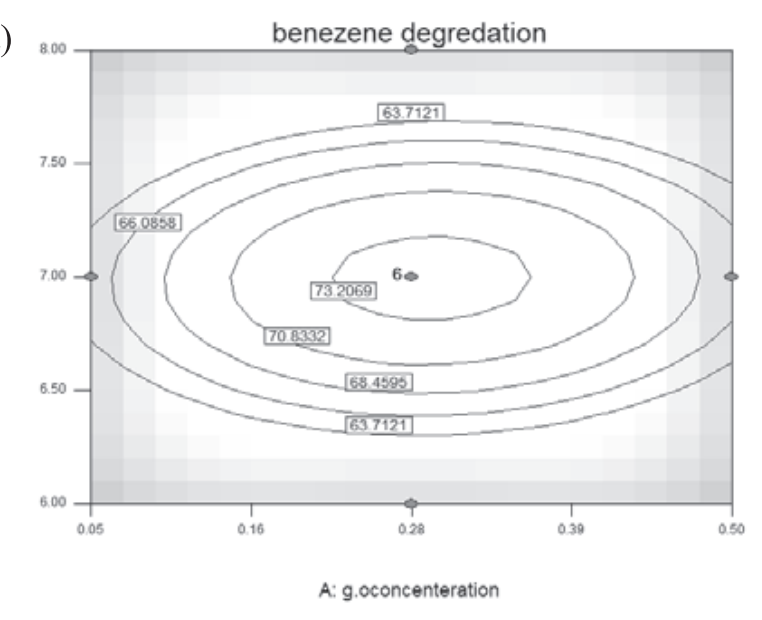

b)

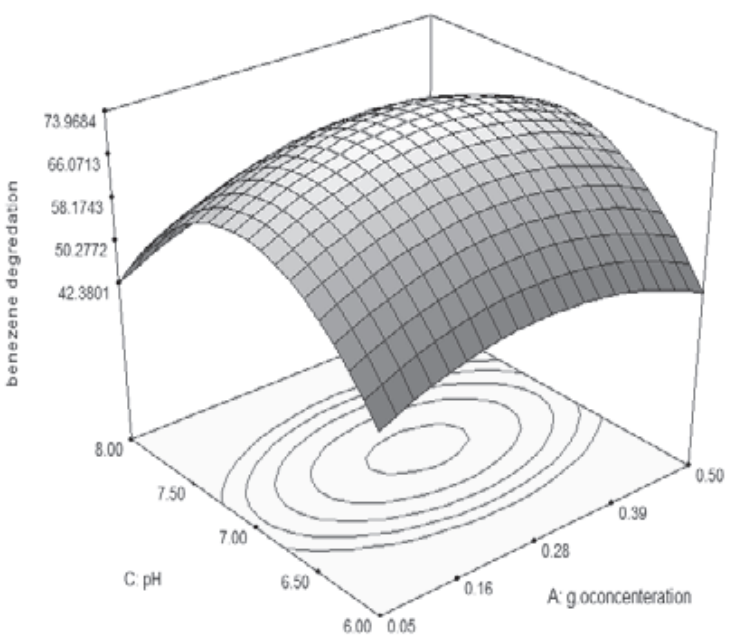

Fig. S1. Interaction effect of $\mathrm{pH}$ and graphene oxide concentration on total benzene removal: a) contour plot and b) surface plot. 
a)

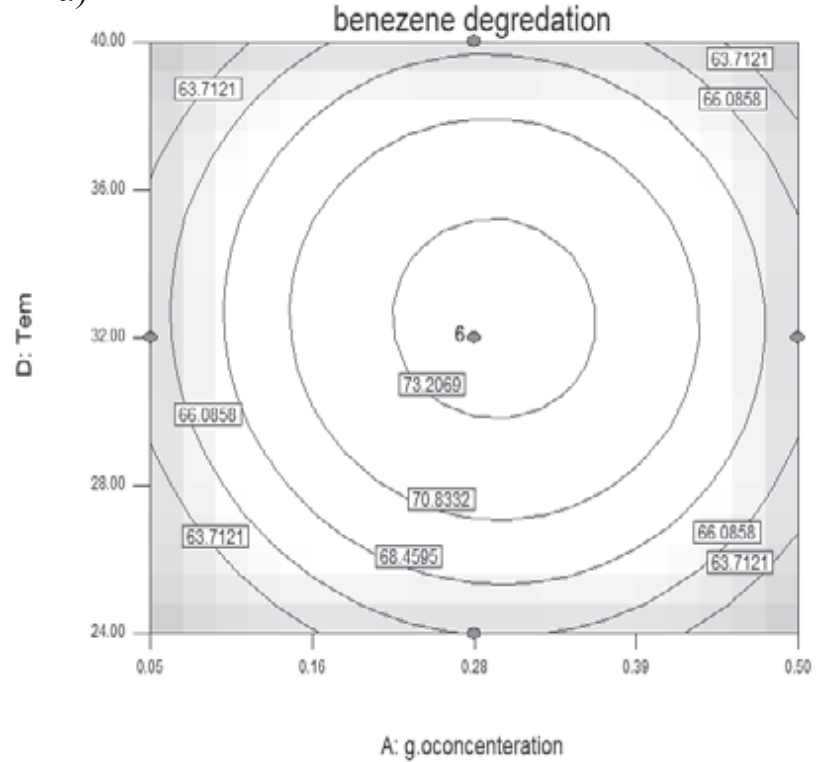

b)

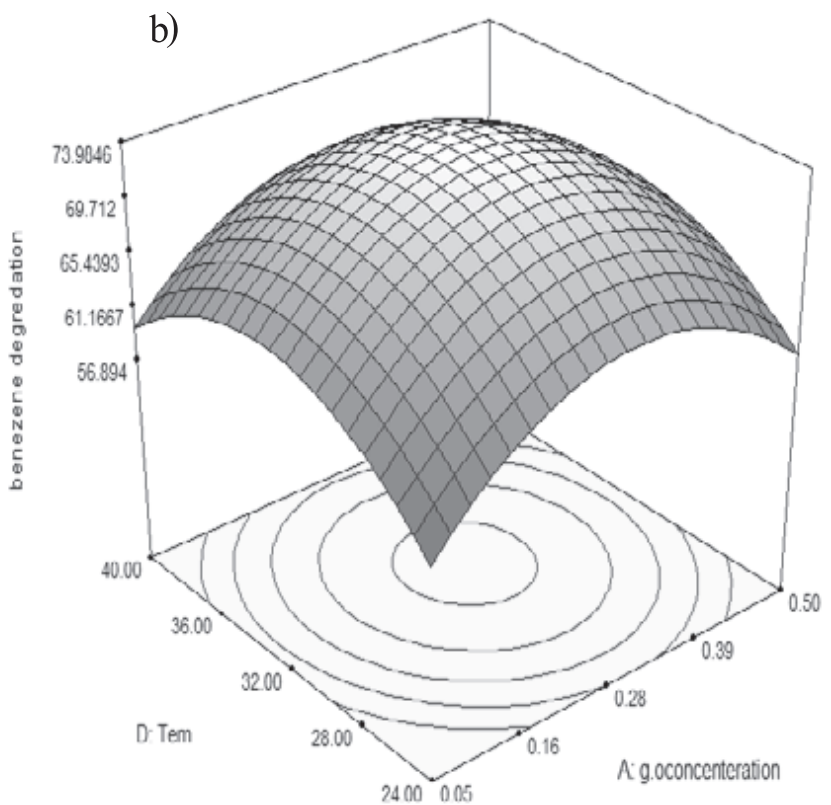

Fig. S2. Interaction effect of temperature and graphene oxide concentration on total benzene removal: a) contour plot and b) surface plot.

a)

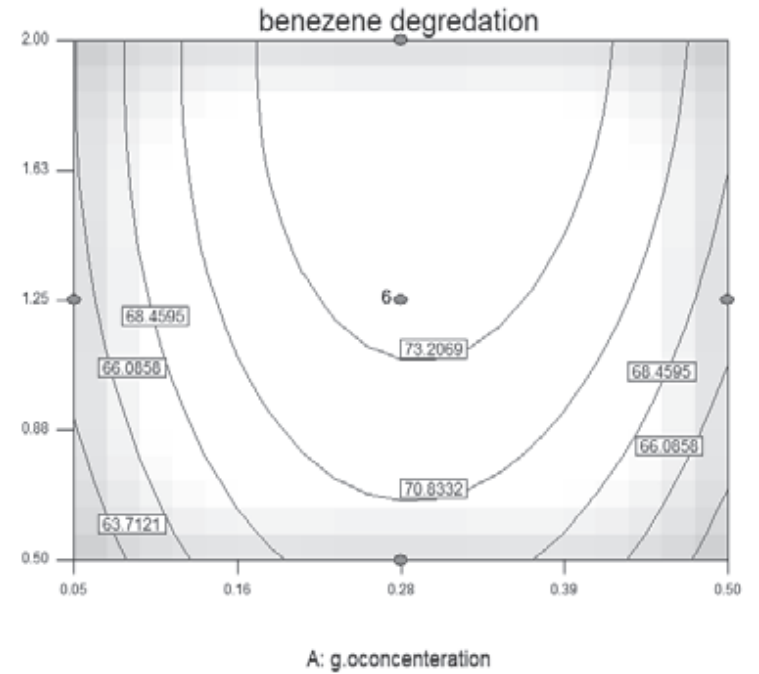

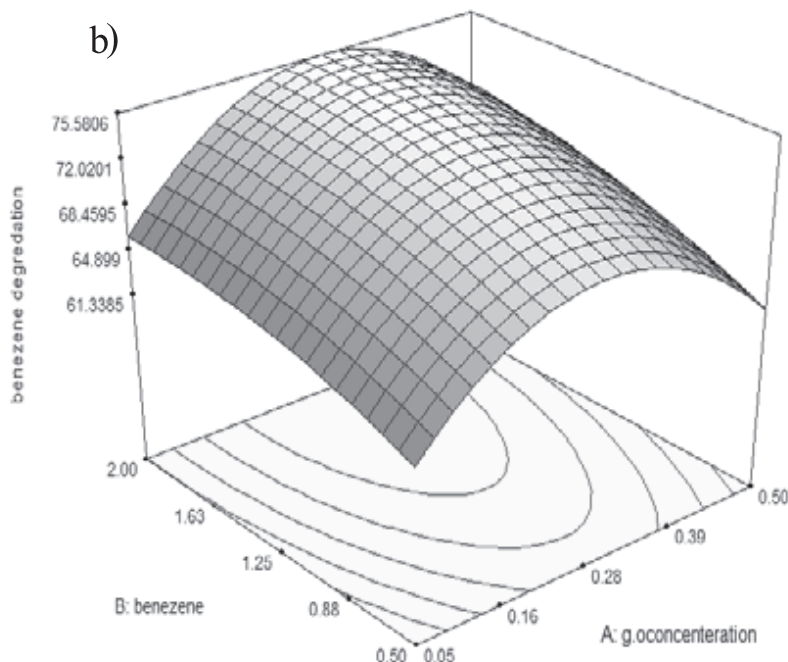

Fig. S3. Interaction effect of benzene concentration and graphene oxide concentration on total benzene removal: a) contour plot and b) surface plot. 

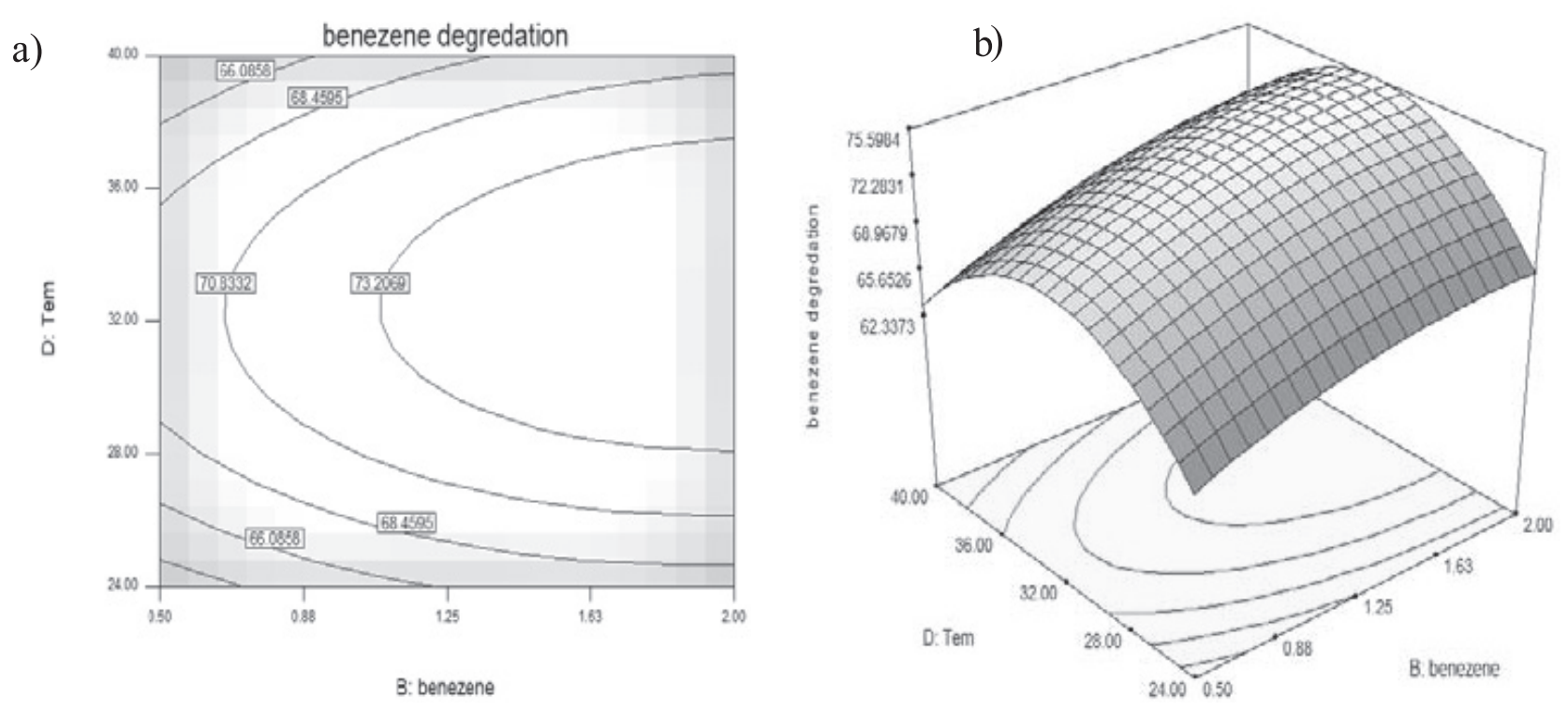

Fig. S4. Interaction effect of temperature and benzene concentration on total benzene removal: a) contour plot and b) surface plot.
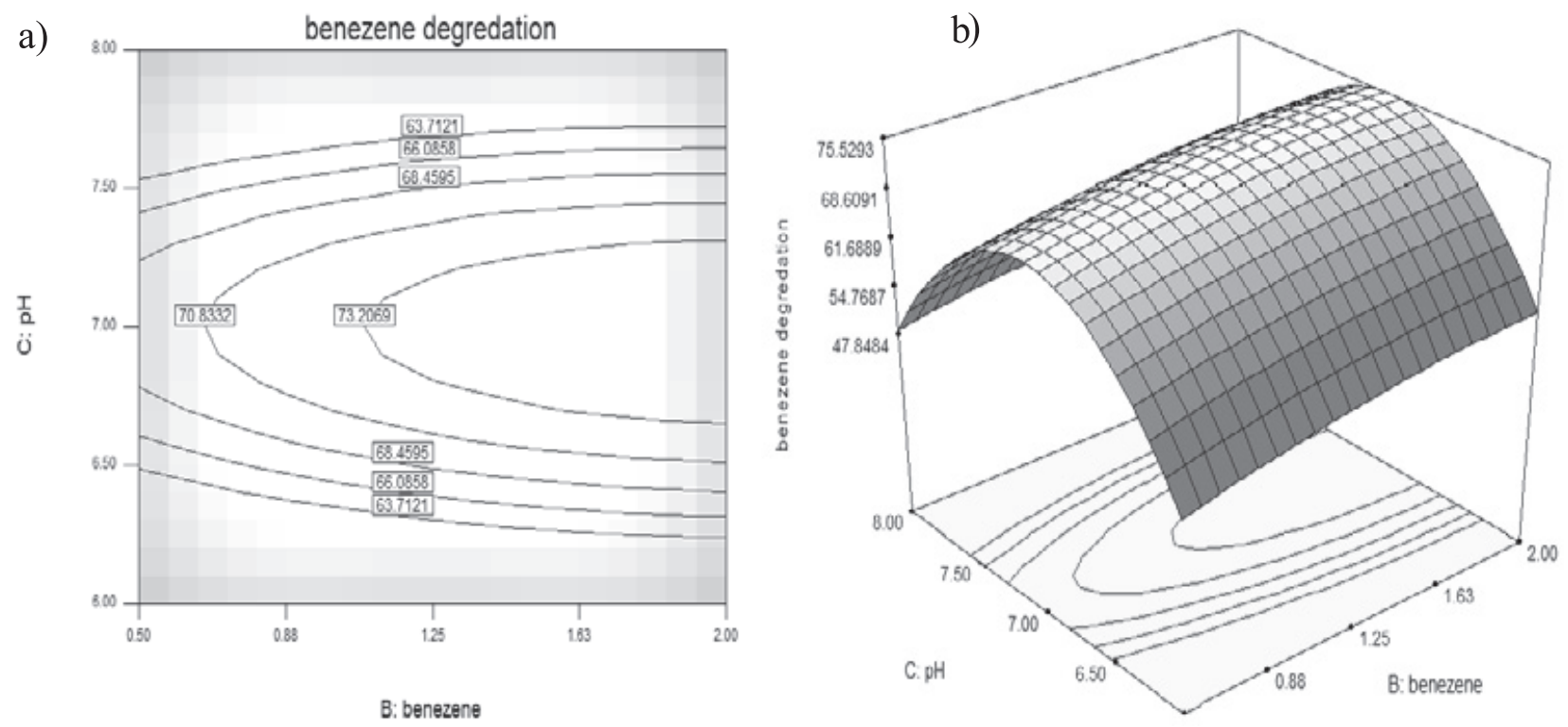

Fig. S5. Interaction effect of $\mathrm{pH}$ and benzene concentration on total benzene removal: a) contour plot and b) surface plot. 
